\title{
Use of WLC (Weighted Linear Combination) to Determine Land Priorities for Development of Paddy Fields in Gorontalo Regency, Indonesia
}

\author{
Erwin L Subandi ${ }^{1}$, Widiatmaka ${ }^{2}$ and Muhammad Ardiansyah ${ }^{3}$ \\ ${ }^{1}$ Student, Department of Soil Science and Management of Land Resources, Bogor Agricultural University, INDONESIA \\ ${ }^{2}$ Lecturer, Department of Soil Science and Management of Land Resources, Bogor Agricultural University, INDONESIA \\ ${ }^{3}$ Lecturer, Department of Soil Science and Management of Land Resources, Bogor Agricultural University, INDONESIA \\ ${ }^{1}$ Correspondence Author: erwinsubandi91@gmail.com
}

\begin{abstract}
Gorontalo Regency has the largest paddy field area in Gorontalo province. The increase in population and the high demand for land for the construction of residential areas, trade areas and services, and the construction of accessibility will put great pressure on paddy fields. Uncontrolled conversion of paddy fields causes a decrease in paddy fields. Paddy fields as a rice-producing container should be maintained and protected so that the paddy needs in Gorontalo Regency are still fulfilled. Optimization of paddy fields needs to be done by the Gorontalo Regency government as an effort to increase the area of paddy fields. This study aims to determine priority lands for the development of paddy fields in Gorontalo Regency. Determination of priority land for growing wetland uses using the Weighted Linear Combination (WLC) method based on geographic information systems (GIS). The parameters used consist of driving factors and inhibiting factors. Types of land use that have land rent are forests, shrubs and moor. The criteria that influence the development of paddy field use are the distance from the paddy fields, the distance from the bush, the distance from the moor, the distance from the river and the distance from the small road. Land that has a high priority for the development of paddy land use is 6,656 ha $(3.01 \%)$, medium priority land is 4,721 ha $(2.16 \%)$, low priority land is 4,671 ha $(2.14 \%)$ and very low priority land for development in paddy field use is 202,155 ha $(92.68 \%)$.
\end{abstract}

Keywords - Paddy Field, Priority Land, Weighted Linear Combination (WLC).

\section{INTRODUCTION}

Paddy fields in Gorontalo Regency have an area of 13,958 ha [1]. The distribution of paddy fields in Gorontalo Regency is mostly in sub urban or peri-urban areas. [2] explains that sub urban areas are areas that experience the highest rate of land use change, especially changes in agricultural land to non-agriculture due to the influence of nearby urban development. Paddy field conversion is a serious threat in realizing food sovereignty, considering that land conversion cannot be avoided while the impact that is generated is permanent, cumulative and progressive [3].
Failure to fulfill food needs such as rice, of course, will have an impact on economic, social and political problems [4]. Based on the results of analysis of Landsat satellite images in 2010-2015, paddy fields in Gorontalo Regency amounted to 543 hectares.

The phenomenon of conversion of paddy fields has caused several losses, such as a decrease in the raw area of paddy fields, reduced production of rice per year, loss of farm income, employment opportunities, and loss of government investment. Meanwhile, demand for rice consumption increases as the population increases. [5], paddy fields that are converted into non-agricultural land have very little chance of turning back into paddy fields. One of the strategies that must be carried out to maintain the availability of rice is to develop raw land for paddy fields. In developing agricultural land such as paddy fields, it must be based on land suitability as a factor in site selection to achieve high productivity [6]. The purpose of this study is to carry out a priority analysis of the development of paddy fields in Gorontalo Regency.

\section{METHODOLOGY}

\section{Analysis of Weighted Linier Combination (WLC)}

GIS-based Weighted Linear Combination (WLC) is one of the multi-criteria evaluation models that are widely used for land suitability analysis, land use, priority land selection, and others through the process of standardizing values, weighting and overlapping (Overlay) [7]. GIS-based WLC can provide explanations and considerations for several criteria in selecting locations that are suitable to be developed for certain activities. According to [8], WLC is a concept that combines maps by applying standardized values to each parameter class and factor weights for the parameters themselves. In this study WLC can be operated using ArcGIS 10.5 software, because it has good ability in analyzing, converting vector to raster/raster to vector and overlapping capabilities. GISbased WLC procedures include: (1) identification of sets of parameters; (2) standardizing attribute values; (3) 
weighting; (4) overlap (overlay). WLC can be used with GIS applications as explained by [9] in equation 1.

$$
V\left(X_{i}\right)=\left(\Sigma_{j} w_{j} r_{i j}\right)\left(\prod_{j} r_{i k}^{*}\right)
$$

Where:

$w_{j} \quad$ : Normal weight

$V\left(X_{i}\right): J$-value attribute function. $\left.x_{i=(} x_{i 1} x_{i 2} \ldots \ldots x_{i n}\right)$

$r_{\mathrm{ij}}^{\mathrm{i}}$ : attributes that are converted into comparable scales

$r_{\text {IE }}^{*} \quad$ : The value given to the cell i-value do the obstacle map

\section{Identification of Work Sets}

The objectives to be achieved in this analysis are land suitability maps based on competing biophysical, socio-economic parameters, commodity competitors, and policies. [10] state that the relationship between goals and criteria has a hierarchical structure or commonly referred to as a value structure that provides guidance for identifying sets of criteria that must be included in the analysis of certain decisions stored in the GIS database. Parameters that have been collected are divided into 2 (two) factors, namely driving factors and constraint factors of land use development. There are 6 ( six) criteria that are assumed to be the driving factors for development in land use, and 5 (five) criteria which are assumed to be the inhibiting factors for land use development, are fully presented in Table 1.

TABLE 1

\begin{tabular}{|c|c|}
\hline Factors & Sets of Criteria \\
\hline Driving & $\begin{array}{l}\text { Distance from the forest } \\
\text { Distance from Small Road } \\
\text { Distance from Paddy Fields } \\
\text { Distance from Shrub Bush } \\
\text { Distance from Water Source } \\
\text { Distance from Moor }\end{array}$ \\
\hline Constraint & $\begin{array}{l}\text { Slope Map } \\
\text { Forest Zone Map } \\
\text { Space Pattern Plan Map } \\
\text { Paddy Field Suitability Map } \\
\text { Other Land Use }\end{array}$ \\
\hline
\end{tabular}

The driving factor for land use development is a criterion that can influence the development/development of a land use. The more and stronger the influence of the driving factors on land use around it, the faster the development process. Meanwhile inhibiting factors are criteria that limit the existence of development in land use based on natural conditions or regulations/policies applied in the research area.

\section{Standardization of Attribute Values}

WLC requires that each value (attribute) on each of the different criteria must be transformed into a unit of comparable value. Standardization of attribute values used is 0 to 1 . The closer to the value of 1 (maximum value), the stronger it is to encourage the development of land use. Conversely, if it is getting closer to 0 (minimum value) then the weaker or less feasible in contributing to the development of land use, in other words the value close to 0 has a considerable limit. The standardization approach of attribute values is based on the assumption of strong linearity [10].

Conversion of inhibiting factors from vector data to raster data based on boolean $\operatorname{logic}(0,1)$. Cell value 0 (false) is represented as an inhibiting cell value, if multiplied by another attribute the output cell value will be 0 (false). Cell value 1 (true) is presented as a living value, in the sense that value 1 can be multiplied by another attribute, the output cell value is $\neq 0$.

The driving factor which is still in the form of vector data, needs to be further analyzed using Eucleadian Distance to calculate the straight distance of each cell of the raster data for each criterion of land use. Cell size resolution of raster data is $30 \mathrm{~m} \times 30 \mathrm{~m}$. The closeness between source location and destination is based on straight line measurements or distance cells as the implicit assumption of linearity between distance and proximity attributes. It should be noted that the transformation used is purely algebraic operations without any preference from decision makers [10].

\section{Weighting Attribute}

Weighting attributes is obtained from the results of binary logistic regression analysis. The expected output from this analysis is the parameters that affect the development of land use. The relationship between changes in land use with driving factors can be evaluated using binary logistic regression analysis [11]. Changes in land use are phenomena or events that are binary in two categories, namely changing or not changing [12]. Logistic regression is a statistical analysis method that can be used to describe the relationship between response variables (dependent variables) that have two categories or more independent variables that are categorical or interval scale [13]. Logistic regression is a regression model that has independent variables that are binary [14]. Binary variables are data that are more inclined to an event, phenomenon, or object that has two responses or values [15]. The tool used in this process is SPSS 19. The logistic regression formula is presented in equation 2 .

$p=\beta_{0}+\beta_{1} X_{1}+\beta_{2} X_{2}+\beta_{4} X_{4}+\cdots+\beta_{12} X_{12}$

Where:

$p \quad$ : Opportunities for land use development

$\beta_{0} \quad$ : Estimated constants

$\beta_{\mathrm{i}} \quad:$ The coefficient for each variable $X_{\mathrm{i}}$ 
$X_{\mathrm{i}} \quad$ : Independent variables

Things that are taken into consideration in logistic regression analysis include: (1) the significance test of parameters (simultaneous and partial) to determine the role of each predictor variable (x) used on the response variable (y) based on the significance level $\alpha \leq 0.05$ with confidence level $95 \%$; and (2) the model compatibility test to find out whether the model has been able to explain the data or not, in the sense that there is no difference between the results of the observations and the results of the model predictions.

The type of land use that is assumed to experience development as obtained from the analysis of changes in land use includes plantations, settlements and places of activity, paddy fields, sugar cane, and moors. Partial test value of the parameter significance of each criterion that has the potential to influence the development of land use is used to determine the weight.

The weighting technique used in this study is the ratio weighting technique. Ratio weighting techniques have similarities to the ranking determination using paired valuation, but in this technique the decision maker must have a comparison number that is different from one attribute to another [16]. After obtaining criteria that affect the development of land use, the first step that needs to be done is to rank the criteria based on their significance using a comparison of virtues. The smaller the significance value, the greater the chance of land use to grow. The next step is to weight the criteria that affect the development of land use by using geometric averages.

Overlay

The overlay procedure on WLC is to multiply each attribute of the standardized development factor for land use with attribute weights. Then add up all the attributes of the driving factors and multiply them by inhibiting the development of land use. The implementation of overlay procedures on WLC can be seen in Figure 1.

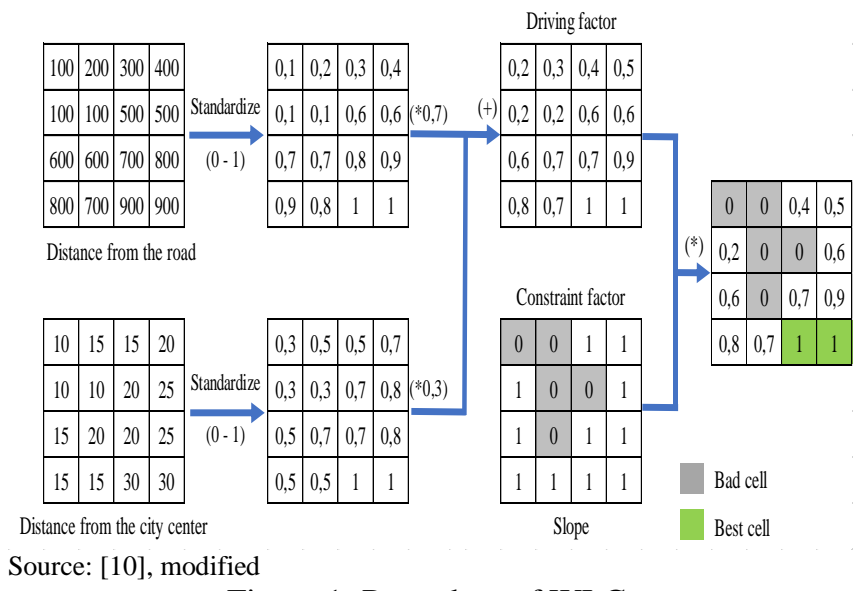

Figure 1: Procedure of WLC

Analysis of overlay driving factors and inhibiting factors produces output in the form of a suitability map, with high priority values ranging from $0-1$. If divided into 4 (four) equal parts, then the value of $0-0.25=$ very low priority, $0.25-0.5=$ low priority, values of $0.5-0.75=$ medium priority and a value of $0.75-1=$ high priority.

\section{OUR APPROACH}

\section{Weighted Linier Combination (WLC) Identification of Set Criteria}

Selection of criteria for distance from paddy fields, distance from shrubs, and distance from moor, based on land rent value. The land rent approach is used because it describes the value or benefits of certain land uses. [17] in his study explained that activities that produce high land rent in general will be able to shift activities that have a lower land rent. The value of agricultural land rent is low so logically economic development will encourage the allocation of land to other economic sectors that lead to conversion of agricultural land [18].

If sorted from those with the lowest to very high land rent value, then the type of land use that has the lowest land rent value is forests and shrubs, following the type of upland land use. Paddy fields have a land rent value higher than the previous type of land use. River is a container provider of water resources that supports the sustainability of agricultural activities. Gorontalo Regency has 18 (eighteen) large river networks, 1 (one) reservoir, and 1 (one) lake. The existence of abundant water resources is very influential on the development of paddy fields. Based on these considerations, the distance from the water source is included in the criteria that influence the development of land use.

The inhibiting factor of paddy field development is other types of land use which have higher land rent values, namely plantations, settlements, and sugarcane. The other criteria for inhibiting factors to consider are the suitability of paddy fields and the spatial pattern of Gorontalo Regency. Land suitability for lowland paddy can only grow on suitable land (S1, S2, S3), while land with large barriers $(\mathrm{N} 1, \mathrm{~N} 2)$ is not assumed to grow. The Gorontalo Regency spatial pattern consists of allotment of protected area space and allocation of space for cultivation areas. Protected areas are areas defined by the main function of protecting environmental sustainability which includes natural resources and artificial resources. Cultivation area is an area defined by the main function to be cultivated on the basis of conditions of natural resources, human resources, and artificial resources (Law No. 26 of 2007). Land in a protected area is assumed not to grow. Land in the cultivation area is assumed to grow.

Standardization of Attribute Values

The results of the analysis of standardization of attribute values on the criteria of driving factors and 
inhibiting factors for land use development can be seen in Figure 2. and Figure 3. Through the standardization process, the attribute values of each criterion that act as the driving factor for paddy field development have the same scale, $0-1$. The attribute value that is getting closer to 1 has a very high suitability, and the attribute value that is getting closer to 0 has a very low suitability. The attribute values of each criterion in the inhibiting factor have the same scale, namely 0 and 1 . The value of attribute 1 is the appropriate value, and the value of attribute 0 is an inappropriate value or has a large limiter.

Figure 2a provides an overview of the standardization of attribute values on the criteria for distance from paddy fields. The green color shows the area close to the paddy fields, while the red color indicates the area far from the paddy fields. Figure $2 b$ provides an overview of the standardization of attribute values for distance criteria from shrubs. Green shows areas close to plantations, while red indicates areas far from plantations. Figure $2 \mathrm{c}$ provides an overview of the standardized attribute values of the distance criteria from moor. The green color shows the moor which is close to the moor, while the red color shows the area far from the moor. Figure $2 \mathrm{~d}$ provides an overview of the standardized attribute values for the distance from a small road. Green shows areas that are close to small roads, while red indicates areas far from small roads. Figure $2 \mathrm{e}$ provides an overview of standardization of attribute values criteria for distance from water sources. The green color shows the area close to the water source, while the red color indicates the area far from the water source. Areas that have very high suitability are visualized in green which has an attribute value of close to 1 , and areas that have very low suitability are visualized in red which has a value of the 0 attribute.

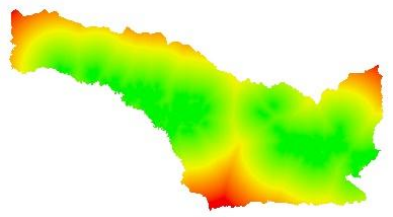

(a)

Distance from paddy fields

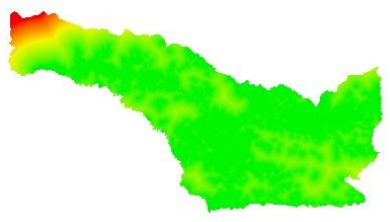

(c)

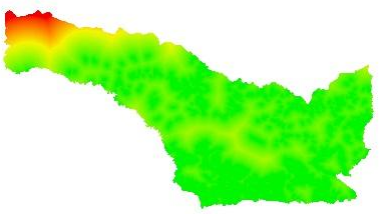

(b)

Distance from shrubs

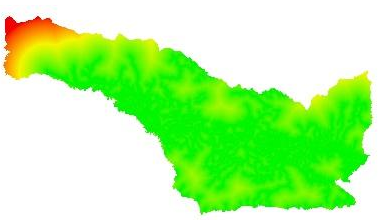

(d)
Distance from moor

Distance from a small road

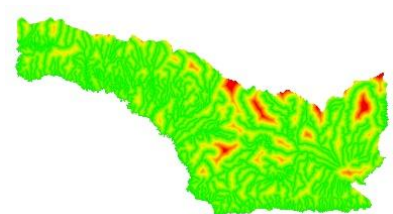

(e)

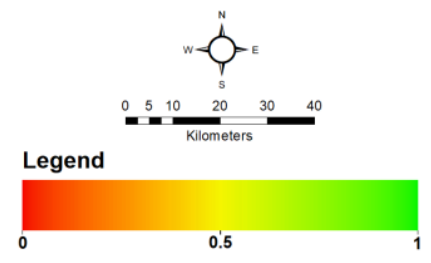

Distance from water sources
Figure 2: Criteria for driving the development of paddy field use

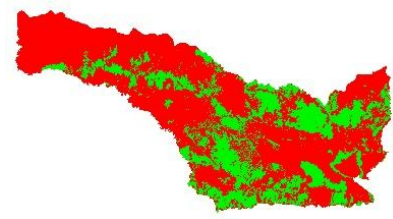

(a)

Other land use

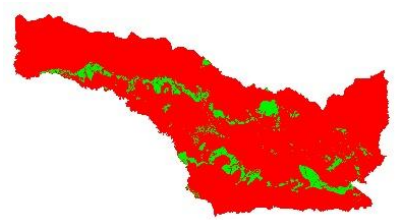

(c)

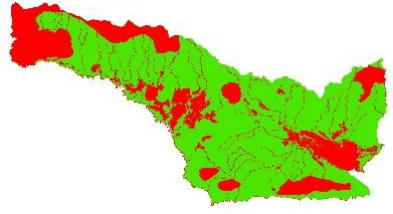

(b)

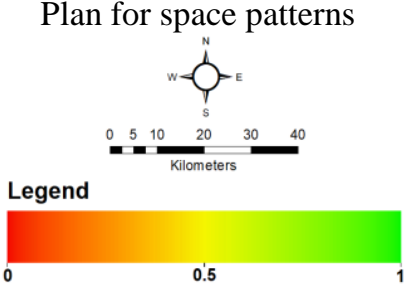

Suitability of paddy fields

Figure 3: Criteria for development inhibitors of wetland land use

Figure $3 a$ provides an overview of the standardization of attribute values on the inhibiting criteria for the development of paddy fields. The green color indicates the area that is suitable for growing paddy fields, and the red color indicates areas that are not suitable or have large obstacles. Figure $3 \mathrm{~b}$ provides an overview of the standardization of attribute values in the spatial pattern plan as a barrier to the development of paddy fields. The green color shows the appropriate area, and the red color indicates an inappropriate area. Figure $3 c$ provides an overview of the standardization of attribute values on land suitability criteria for wetland rice as a barrier to the development of paddy fields. Green indicates the appropriate area, and the red color indicates the area that is not suitable for the development of paddy fields.

\section{Weighting Attributes}

The attribute weighting value for the criteria that affect the development of land use is obtained from the results of binary logistic regression analysis. The type of land use which is the response variable (y) is paddy field, while the predictor variable ( $\mathrm{x}$ ) which is assumed to affect 
the development of land use based on the results of identification of set of criteria includes: (1) distance from paddy fields; (2) distance from bushes; (3) distance from moor; (4) distance from a small road; and (5) distance from the water source. Variable (y) consists of 2 (two) categories denoted by $\mathrm{y}=1$ (growing), and $\mathrm{y}=0$ (not growing).

The results of logistic regression analysis of the development of paddy fields obtained by the value of test parameters simultaneously (overall test) is 0,000. The significance value of parameters simultaneously which is less than $\alpha(0.05)$ with a confidence level of $95 \%$ gives the conclusion that at least one independent variable has an effect on the response variable. Based on Table 2 the partial test value of the significance (partial test) which is less than $\alpha(0.05)$ with a confidence level of $95 \%$, indicates that the independent variables that affect the development of paddy fields in Gorontalo Regency are distance from small roads, distance from rivers, distance from moor, distance from shrubs, and distance from paddy fields. The results of the model compatibility test (Hosmer and Lemeshow Test) obtained a significance value of 0.601 . The significance value of the model compatibility test is more than $\alpha(0.05)$ with a confidence level of $95 \%$, giving the conclusion that the logistic regression model used has been able to explain the data.

TABLE 2

Partial test value of parameter significance (partial test)

\begin{tabular}{lc}
\hline Criteria affect the development of wetland use & Paddy fields \\
\hline Distance from a small road & 0.048 \\
Distance from the river & 0.043 \\
Distance from moor & 0.036 \\
Distance from shrubs & 0.012 \\
Distance from paddy fields & 0.000 \\
\hline
\end{tabular}

The binary logistic regression method approach produces criteria that affect the development of paddy fields. Determination of weighting value based on partial significance test value. The smaller the significance value, the greater the effect on the development of paddy fields in Gorontalo Regency. Partial significance test value (partial test) is presented in Table 2. [19] in his research shows that the distance from the road and the distance from the city center affect the settlement development. The development of paddy fields is influenced by the distance from existing paddy fields, the distance from the bush, and the distance from the moor, the distance from the water source, and the distance from the small road. The results of the weighting ratio analysis obtained the weight values of each criterion that influence the development of land use. The weight values of each criterion are presented in Table 3.
TABLE 3

Weight values of criteria that affect the development of land use

\begin{tabular}{lc}
\hline Criteria Influencing Development in the use of paddy fields & Weight \\
\hline Distance from a small road & 0.06 \\
Distance from the river & 0.10 \\
Distance from moor & 0.16 \\
Distance from shrubs & 0.26 \\
Distance from paddy fields & 0.42 \\
\hline
\end{tabular}

\section{Overlay}

The results of the analysis of overlapping driving factors and the inhibiting factors for the development of wetland use have resulted in a development priority map. In Figure 4, green shows the development priority of high paddy field use, light green color indicates the development priority of moderate wetland use, yellow indicates the development priority of low paddy land use, and the red color shows the priority of the development of very low wetland land use.

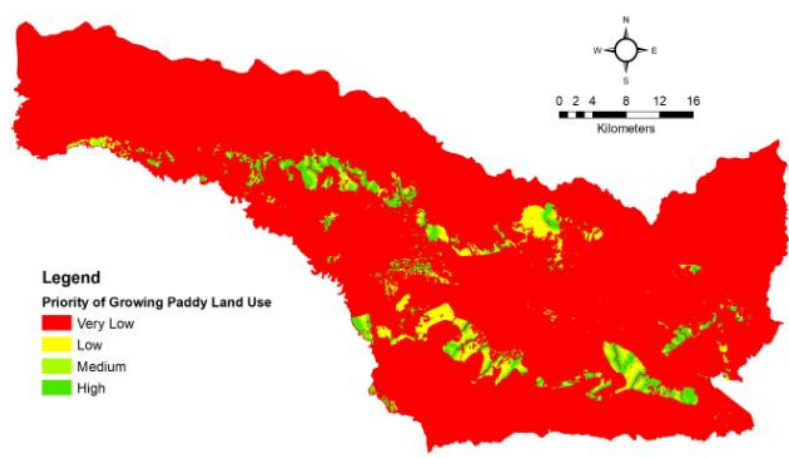

Figure 4: Priority map for the development of wetland use

Very low priority land for the development of paddy field use has an area of 20.155 ha with a percentage of $92.68 \%$. Low priority land for the development of paddy field use has an area of 4,671 ha, with a percentage of $2.14 \%$. Medium priority land for development in the use of paddy fields has an area of 4,721 ha with a percentage of $2.16 \%$. High priority land for the development of paddy field use has an area of 6,565 ha with a percentage of $3.01 \%$. Very low priority land for the development of wetland use has a large limitation/constraint based on physical, social, economic and policy interventions.

\section{CONCLUSION}

The criteria that influence the development of paddy field use are the distance from the paddy fields, the distance from the bush, the distance from the moor, the distance from the river, and the distance from the small road. Land that has a high priority for the development of 
paddy land use is 6,656 ha $(3.01 \%)$, medium priority land is 4,721 ha $(2.16 \%)$, low priority land is 4,671 ha $(2.14 \%)$ and very low priority land for development in paddy field use is 202,155 ha $(92.68 \%)$.

\section{REFERENCES}

[1] Badan Pusat Statistik Kabupaten Gorontalo. (2016). Kabupaten gorontalo dalam angka. Gorontalo (ID): Badan Pusat Statistik Kabupaten Gorontalo.

[2] Rahayu S. (2009). Kajian konversi lahan pertanian di daerah pinggiran kota yogyakarta bagian selatan studi kasus dibagian daerah kecamatan umbulharjo. Jurnal Pembangunan Wilayah dan Kota, 5(3), 365-372.

[3] Irawan B. (2005). Konversi lahan sawah: potensi dampak, pola pemanfaatannya, dan faktor determinan. Forum Penelitian Agro Ekonomi, 23(1), 1-18

[4] Saifullah A dan Sulandari E. (2010). Prospek beras dunia 2010: Akankah kembali melonjak. Jurnal Pangan, 19(2), 135-146.

[5] Pasandaran E. (2006). Alternatif kebijakan pengendalian konversi lahan sawah beririgasi di Indonesia. Jurnal Litbang Pertanian, 25(4), 123-129.

[6] Widiatmaka, Ambarwulan W, Sutandi A, Murtilaksono K, Munibah K, \& Daras U. (2015). Suitable and available land for cashew (Anacardium occidentale L.) in the island of Lombok, Indonesia. Journal of Applied Horticulture, 17(2), 129-139

[7] Malczewski J. (2004). GIS-based land-use suitability analysis: A critical overview. Progress in Planning, 62, 365.

[8] Yalcin A. (2008). GIS based landslide susceptibility mapping using analytical hierarchy process and bivariate statistic in adresen (Turkey): Comparisons of result and confirmations. CATENA, 72(1), 1-12.

[9] Eastman JR, Jin W, Kyem PAK, \& Toledano J. (1995). Raster procedures for multi-criteria/multi-objective.
Photogrametric Engineering and Remote Sensing, 61, 53947.

[10] Malczewski J \& Rinner. (2015). Multicriteria decision analysis in geographic information science. New York, US: Springer Science.

[11] Verburg PH, Veldkamp WSE, Espaldon RLV, \& Matsura SSA. (2002). Modelling the spatial dinamics of regional land use: The clue-S model. Enviromental Management, 30(3), 391-405. doi: 10.1007/s00267-0022630-x.

[12] Nahib I \& Turmudi, Suwarno Y. (2015). Pemodelan spasial deforestasi di kabupaten tasikmalaya, provinsi jawa barat. Majalah Ilmiah Globe, 17(2), 155-164.

[13] Hosmer DW \& dan Lemeshow S. (2000). Applied logistic regression. ( $2^{\text {nd }}$ ed.). New York, US: John Wilay \& Son, Inc.

[14] Yudarwati R. (2016). Perubahan penggunaan lahan dan arahan pengendaliannya di kabupaten bogor dan cianjur [tesis]. Bogor (ID): Program Pascasarjana, Institut Pertanian Bogor.

[15] Ruslisan, Zahira FS, \& Dharmasanti R. (2015). Prediksi perubahan penggunaan lahan terbangun terhadap kesesuaian rancangan tata ruang wilayah menggunakan regresi logistic binner berdasarkan data spasial dan penginderaan jauh di kota semarang. Proceedings, 51-67.

[16] Basyaib F. (2006). Teori pembuatan keputusan. Jakarta (ID): Grasindo.

[17] Nofarianty. (2007). Analisis potensi lahan sawah untuk pencadangan kawasan produksi beras di kabupaten agam-sumatera barat [tesis]. Bogor (ID): Program Pascasarjana , Institut Pertanian Bogor.

[18] Sitorus SRP. (2017). Perencanaan penggunaan lahan. Bogor (ID): IPB Press.

[19] Rafiudin A. (2016). Model spasial perubahan penggunaan lahan untuk mempertahankan kabupaten karawang sebagai kontributor beras nasional [tesis]. Bogor (ID): Program Pascasarjana, Institut Pertanian Bogor. 